\title{
PENGARUH PENAMBAHAN LILIN LEBAH DAN NANOPARTIKEL SENG OKSIDA TERHADAP SIFAT FISIK DAN MEKANIS FILM BERBASIS KITOSAN
}

\author{
[Effect of Beeswax and Zinc Oxide Nanoparticles Addition on The Physical and \\ Mechanical Properties of Chitosan Based Film]
}

\author{
Novan Nandiwilastio ${ }^{1) \star}$, Tien R. Muchtadii'), Nugraha E. Suyatma ${ }^{2)}$, dan Sri Yuliani ${ }^{4)}$ \\ ${ }^{1)}$ Program Studi Magister Ilmu Pangan, Sekolah Pascasarjana, Institut Pertanian Bogor, Bogor \\ 2) Departemen IImu dan Teknologi Pangan, Fakultas Teknologi Pertanian, Institut Pertanian Bogor, Bogor \\ 3) Balai Besar Penelitian dan Pengembangan Pascapanen Pertanian, Bogor
}

Diterima 7 Mei 2018 / Disetujui 6 Mei 2019

\begin{abstract}
Chitosan-based films showed good gel formation capability and gas permeability $\left(\mathrm{CO}_{2}\right.$ and $\left.\mathrm{O}_{2}\right)$. However, the high permeability of water vapor limits the application of chitosan as a single coating material. Additionally, single chitosan film was also brittle, so the addition of lipid and metal nanoparticles were chosen to solve this problem. This research aimed to determine the effect of the addition of beeswax emulsion and zinc oxide nanoparticles (ZnO-NPs) on the physical and mechanical properties of chitosan based films. The film was prepared by dissolving ZnO-NPs (0, 1 and 2\% by weight of chitosan) into 100 $\mathrm{mL}$ of distilled water followed by the addition $1 \mathrm{~g}$ of chitosan and or, addition of beeswax emulsion $(0$ and $5 \%$ by the volume of solution). The result showed that the addition of beeswax emulsion ZnO-NPs into chitosan based film significantly decreased WVTR value from 24.03 to $10.38 \mathrm{~g} / \mathrm{m}^{2}$ hours and the tensile strength value from 8.30 to $6.92 \mathrm{Mpa}$. The addition of beeswax emulsion and ZnO-NPs also changed the physical properties of chitosan-based film significantly; in terms appearance, color and thickness. Meanwhile, the film elongation percentage changed significantly in the range of 30.36 to $50.09 \%$ when $\mathrm{ZnO}$ NPs was added into chitosan-based film solution. Overall, the addition of beeswax and ZnO-NPs showed improvement of the physical and mechanical properties of chitosan-based films so that better packaging of fresh food products can be developed.
\end{abstract}

Keywords: beeswax, packaging, chitosan, film, zinc oxide

\begin{abstract}
ABSTRAK
Film berbasis kitosan mampu membentuk gel dan permeabilitas gas $\left(\mathrm{CO}_{2}\right.$ dan $\left.\mathrm{O}_{2}\right)$ yang baik. Namun, permeabilitas uap air yang tinggi membatasi penggunaan kitosan sebagai bahan pelapis tunggal. Karakteristik film kitosan juga cenderung rapuh sehingga tambahan senyawa lipid dan nanopartikel logam diperlukan untuk mengatasi berbagai permasalahan tersebut. Penelitian ini bertujuan mengevaluasi pengaruh tambahan emulsi lilin lebah dan nanopartikel seng oksida (NP-ZnO) terhadap sifat fisik dan mekanis film berbasis kitosan. Film dibuat dengan melarutkan NP-ZnO (0,1 dan 2\% dari berat kitosan) ke dalam $100 \mathrm{~mL}$ akuades dan diikuti dengan penambahan $1 \mathrm{~g}$ kitosan dan atau, ditambahkan dengan emulsi lilin lebah ( 0 dan $5 \%$ dari volume total larutan). Hasil penelitian menunjukkan bahwa penambahan emulsi lilin lebah dan NP-ZnO pada film berbasis kitosan secara signifikan menurunkan nilai WVTR dari 24,03 menjadi $10,38 \mathrm{~g} / \mathrm{m}^{2}$ jam dan menurunkan nilai kuat tarik dari 8,30 menjadi 6,92 Mpa. Penambahan emulsi lilin lebah dan NP-ZnO juga mengubah sifat fisik film berbasis kitosan secara signifikan antara lain dari segi penampakan, warna dan ketebalan. Sementara itu, nilai elongasi film cenderung berubah signifikan dengan rentang variasi 30,36 hingga 50,09\% ketika diberi penambahan NP-ZnO. Secara keseluruhan, penambahan lilin lebah dan NP-ZnO mampu memperbaiki sifat fisik dan mekanis film berbasis kitosan, sehingga kemasan produk pangan segar yang lebih baik dapat tercipta.
\end{abstract}

Kata kunci: film, kemasan, kitosan, lilin lebah, seng oksida

\footnotetext{
${ }^{*}$ Penulis Korespondensi:

Email: nandiwilastio.novan@gmail.com
} 


\section{PENDAHULUAN}

Penggunaan kemasan alternatif yang berasal dari biopolimer alami merupakan salah satu solusi terbaik dalam mengurangi penggunaan kemasan berbahan plastik yang mempunyai efek negatif terhadap lingkungan. Film dan pelapis pangan dari bahan alami merupakan pilihan terbaik yang banyak dikembangkan karena selain mampu mempertahankan kualitas produk pangan, sifatnya yang edibel dan biodegradable menjadi nilai tambah tersendiri. Pelapis dengan karakteristik permeabilitas yang selektif terhadap air, $\mathrm{O}_{2}, \mathrm{CO}_{2}$ dan etilena dapat mengendalikan respirasi dan menghambat pertumbuhan mikroorganisme pembusuk dan patogen dalam bahan pangan (Abbasi et al., 2009). Salah satu jenis pelapis yang banyak dikembangkan untuk mempertahankan mutu dan memperpanjang umur simpan produk pangan terutama buah, sayur dan kacangkacangan adalah pelapis nanokomposit. Nanokomposit sendiri merupakan polimer yang dikombinasikan dengan sejumlah kecil (maksimal 5\% b/b) partikel berukuran nano yang nantinya dapat meningkatkan performa dari polimer tersebut. Peningkatan yang dimaksud adalah peningkatan sifat fisik, mekanis serta permeabilitas terhadap gas dan air pada film (Sekhon, 2014).

Penggunaan biopolimer berupa kitosan sebagai bahan pelapis dan film telah banyak dikembangkan di dunia pangan. Kitosan merupakan polimer karbohidrat alami hasil deasetilasi kitin atau poli- $\beta-(1 \rightarrow 4)$ $\mathrm{N}$-asetil-D-glukosamin dengan sifat fungsional sebagai antimikroba yang mampu menghambat pertumbuhan berbagai khamir, kapang serta bakteri pembusuk dan patogen (Fernandez-Saiz et al., 2009; Elsabee dan Abdou, 2013). Film berbasis kitosan juga mempunyai sifat mekanis dan permeabilitas gas $\left(\mathrm{CO}_{2}\right.$ dan $\left.\mathrm{O}_{2}\right)$ yang baik. Meskipun demikian, tingginya permeabilitas uap air membatasi aplikasi penggunaan kitosan sebagai bahan pelapis. Penambahan senyawa lipid mutlak dibutuhkan untuk memperbaiki masalah tersebut. Salah satu jenis lipid yang potensial adalah lilin lebah yang tersusun dari $35-45 \%$ lilin monoester linier dan hidroksi monoester, $15-27 \%$ lilin ester kompleks, 12-16\% hidrokarbon, $12-14 \%$ asam lemak bebas dan beberapa material residu lain (Fratini et al., 2016). Tujuan lipid dikombinasikan ke formulasi film berbasis hidrokoloid adalah untuk meningkatkan karakteristik penghalang air dan mengubah penampilan visual film tersebut menjadi lebih baik (Elsabee dan Abdou, 2013). Penelitian Zhang et al. (2014) menyatakan bahwa kombinasi $3 \% \mathrm{~b} / \mathrm{v}$ kitosan dan lilin lebah mampu menurunkan laju perpindahan uap air hingga $52,8 \mathrm{~g} / \mathrm{m}^{2}$ per hari. Kombinasi lilin lebah dengan kitosan juga mampu menghasilkan pelapis dengan nilai laju perpindahan uap air yang lebih kecil dibandingkan kombinasi lilin lebah dengan bahan lain seperti misalnya sodium alginat. Sementara itu, pembuatan film dengan penambahan $10 \%$ lilin lebah terbukti mampu menurunkan permeabilitas uap air dan permeabilitas $\mathrm{O}_{2}$ masing-masing 32 dan 90\% (Marques, 2012).

Pada dasarnya, film berbasis emulsi kurang efisien terhadap transfer air dibandingkan film bilayer karena distribusi yang tidak homogen dari lipid. $\mathrm{Na}$ mun, film berbasis emulsi punya keunggulan untuk menunjukkan ketahanan mekanis yang baik dan hanya membutuhkan satu langkah pembuatan dibandingkan film multilayer yang membutuhkan banyak langkah. Penambahan lipid ke larutan nanokomposit dalam bentuk emulsi lebih efektif daripada lipid berbentuk utuh karena apabila semakin kecil ukuran globula lipid yang dihasilkan, maka lipid tersebut akan lebih stabil dan merata ketika dicetak menjadi film (Karbowiak et al., 2007). Pada penelitian ini, penambahan nanopartikel seng oksida (NP$\mathrm{ZnO}$ ) pada larutan film berbasis kitosan dan emulsi lilin lebah diharapkan mampu meningkatkan kualitas sifat fisik dan mekanis film yang dihasilkan. Inkorporasi NP-ZnO dalam film berbasis kitosan telah terbukti mampu meningkatkan afinitas air dan nilai sudut kontak air yang mengindikasikan permukaan film tersebut menjadi semakin hidrofobik. Penambahan NP-ZnO pada bahan lain seperti PVC diketahui juga mampu meningkatkan ketebalan film dan menurunkan laju transmisi air (Al-Naamani et al., 2016; Li et al., 2009). Parameter film yang diuji antara lain ketebalan, warna, laju transmisi uap air, kuat tarik dan elongasi untuk menggambarkan kualitas film tersebut. Penelitian ini bertujuan untuk mengetahui pengaruh penambahan emulsi lilin lebah dan nanopartikel seng oksida pada persentase tertentu terhadap kerakteristik fisik dan mekanis film berbasis kitosan.

\section{BAHAN DAN METODE}

\section{Bahan}

Bahan utama pembuatan film dalam penelitian ini antara lain kitosan food grade dengan derajat deasetilasi $88,16 \%$ dan rata-rata berat molekul $171,79 \mathrm{KDa}$ (PT. Biotech Surindo, Indonesia), nanopartikel seng oksida (NP-ZnO) dengan ukuran partikel rata-rata $20 \mathrm{~nm}$ (Wako, Jepang) dan lilin lebah yang diperoleh dari petani madu di Bogor.

\section{Pembuatan emulsi lilin lebah}

Pembuatan emulsi lilin lebah merupakan modifikasi metode yang dikemukakan oleh RamnananSingh (2012). Sebanyak $20,3 \mathrm{~g}$ lilin lebah ditimbang dan dilelehkan menggunakan hot plate stirrer (Sigma-Aldrich, USA) pada suhu $70^{\circ} \mathrm{C}$ hingga leleh sempurna. Setelah itu, ditambahkan dua jenis pengemulsi yaitu 29,8 g Tween 60 (Brataco, Indonesia) yang sebelumnya telah dipanaskan pada suhu minimal $70^{\circ} \mathrm{C}$ dan $10,9 \mathrm{~g}$ Span 60 (Brataco, 
Indonesia). Kemudian sebanyak $140 \mathrm{~mL}$ akuades (suhu $70^{\circ} \mathrm{C}$ ) ditambahkan sedikit demi sedikit pada campuran sambil terus diaduk. Selanjutnya, campuran dihomogenisasi pada kecepatan $10.000 \mathrm{rpm}$ selama 13 menit menggunakan ultra turax (IKA T25, Jerman) agar tercampur sempurna. Busa yang terbentuk dipisahkan dari emulsi dan dipindahkan pada wadah lain sebelum dicampur dengan bahan baku lain.

\section{Pembuatan larutan film}

Pembuatan larutan film mengacu pada modifikasi metode yang dikemukakan oleh Marques (2012) dan Meindrawan et al. (2016). Proses pembuatan larutan dilakukan dengan basis kitosan sebesar $1 \%$ (b/v total larutan film). Mula-mula NP-ZnO $(0$, 1 dan $2 \%$ b/b kitosan) dimasukkan ke dalam gelas beaker berisi akuades $100 \mathrm{~mL}$ yang selanjutnya dihomogenisasi dengan ultra turax selama 10 menit pada kecepatan 15000 rpm. Kemudian, $1 \mathrm{~g}$ kitosan dan $1 \mathrm{~mL}$ asam asetat (Brataco, Indonesia) ditambahkan ke dalam gelas beaker tersebut yang dilanjutkan dengan pengadukan selama 4-5 jam menggunakan hot plate stirrer hingga homogen (tanpa endapan). Setelah homogen, dilakukan pemanasan dan pengadukan menggunakan hot plate stirrer yang kemudian ditambahkan $0,25 \mathrm{~g}$ gliserol (Ecogreen Oleochemical, Indonesia) (25\% b/b kitosan) dan lilin lebah ( 0 dan $5 \% \mathrm{v} / \mathrm{v}$ total larutan) ketika larutan mencapai suhu $60^{\circ} \mathrm{C}$. Setelah suhu larutan mencapai $80^{\circ} \mathrm{C}$, pemanasan dihentikan sambil tetap dilakukan pengadukan selama 5 menit hingga menjadi larutan film. Sebanyak 6 formulasi film dihasilkan yaitu: B0Z0 (kitosan saja), B1Z0 (kitosan+lilin lebah), B0Z1 (kitosan+1\% NP-ZnO), B0Z2 (kitosan $+2 \%$ NP-ZnO), B1Z1 (kitosan+lilin lebah $+1 \%$ NP$\mathrm{ZnO}$ ) serta B1Z2 (kitosan+lilin lebah+2\% NP-ZnO).

\section{Pencetakan film}

Pembuatan film dari larutan film ini berdasarkan modifikasi metode yang dikemukakan Marques (2012). Sebanyak $25 \mathrm{~mL}$ larutan film dituang ke dalam cawan petri plastik dan didiamkan selama 48 jam dalam suhu ruang hingga kering. Film yang telah kering diangkat dan dicongkel dari cawan petri plastik kemudian dibungkus dalam alumunium foil dan disimpan dalam desikator dengan $\mathrm{RH} 53 \%$ selama 48 jam hingga stabil.

\section{Karakterisasi sifat fisik film}

Sifat fisik film yang diuji dalam penelitian ini antara lain ketebalan, warna dan laju transmisi uap air/water vapor transmission rate (WVTR). Ketebalan film diukur dengan menggunakan mikrometer sekrup dengan akurasi hingga $0,01 \mathrm{~mm}$. Pengukuran dilakukan sebanyak 5 kali pada titik atau tempat yang berbeda yang mana ketebalan film merupakan rata-rata dari nilai yang terukur.
Warna film diukur menggunakan instrumen chromameter (Minolta, Jepang) dengan plat standar berwarna putih $(L=100, a=-0,01$ dan $b=0,01$ ) yang digunakan sebagai latar pengukuran sampel. Parameter warna Hunter $L$, a dan $b$ dihitung dari rata-rata 5 titik pengukuran yang berbeda dari setiap sampel film dan diulang sebanyak 3 kali. Total perbedaan warna $(\Delta \mathrm{E})=\left[(\Delta \mathrm{L})^{2}+(\Delta \mathrm{a})^{2}+(\Delta \mathrm{b})^{2}\right]^{0,5}$, dimana $\Delta \mathrm{L}, \Delta \mathrm{a}$ dan $\Delta b$ merupakan perbedaan warna antara plat standar dan sampel film (Kanmani dan Rhim, 2014).

Laju transmisi uap air film diukur menggunakan metode ASTM (1993) yang dimodifikasi wadah pengukurannya. Wadah yang digunakan mempunyai permeabilitas uap air yang sangat kecil sehingga diasumsikan tidak memengaruhi pengukuran. Sampel film dipotong dalam bentuk silinder dengan diameter $30 \mathrm{~mm}$ dan dilekatkan pada wadah permeansi yang kemudian disimpan dalam desikator pada $25^{\circ} \mathrm{C}$. Gradien $\mathrm{RH}$ diantara film dijaga dengan meletakkan $\mathrm{CaCl}_{2}$ anhidrat (Merck, Jerman) dengan $\mathrm{RH}$ $2 \%$ di dalam wadah permeansi dan larutan $\mathrm{KCl}$ jenuh (Merck, Jerman) dengan $\mathrm{RH}$ 85\% dalam desikator. Wadah permeansi ditimbang secara berkala sehingga laju transmisi uap air film (water vapour transmission rate/WVTR) $\left(\mathrm{g} / \mathrm{m}^{2} \mathrm{jam}\right)$ dapat dihitung dari kemiringan garis (slope) yang dihasilkan dari analisis regresi bobot sebagai fungsi waktu.

\section{Karakterisasi sifat mekanis film (ASTM, 2002)}

Sifat mekanis film dianalisis menggunakan instrumen microcomputer controlled universal testing machine (Instron, USA). Film dipotong dengan pola tertentu berukuran $2 \times 7 \mathrm{~cm}$. Initial grip diatur pada 17 $\mathrm{mm}$ dengan kecepatan tarik $20 \mathrm{~mm} /$ menit. Kuat tarik dihitung berdasarkan beban maksimum saat film putus sedangkan elongasi berdasarkan selisih perpanjangan film awal dan saat putus. Nilai kuat tarik merupakan nilai gaya kuat tarik $(\mathrm{N})$ dibagi luas area penampang bidang gaya $\left(\mathrm{m}^{2}\right)$, sedangkan persen elongasi merupakan selisih panjang akhir $(\mathrm{m})$ dan panjang akhir $(\mathrm{m})$ dibagi dengan panjang awal kemudian dikalikan $100 \%$.

\section{Rancangan penelitian dan analisis data}

Rancangan penelitian yang digunakan adalah rancangan acak lengkap (RAL) faktorial yang disusun secara fungsional dengan 2 faktor yaitu penambahan emulsi lilin lebah dan NP-ZnO yang semuanya dikombinasikan dengan kitosan. Faktor I terdiri dari 2 level (emulsi lilin lebah 0 dan 5\%) dan faktor II terdiri dari 3 level (NP-ZnO 0, 1, dan 2\%) dengan 3 kali ulangan percobaan untuk tiap kombinasi faktor. Hasil pengukuran dan uji terhadap film dianalisis secara statistika dengan analysis of variant (ANOVA) menggunakan program SPSS Statistics 23. Apabila dari hasil uji terdapat perbedaan maka dilanjutkan dengan uji DMRT dengan taraf 5\% untuk melihat perbedaan antar perlakuan. 


\section{HASIL DAN PEMBAHASAN}

\section{Ketebalan film}

Ketebalan suatu film berkontribusi pada sifat fisik dan mekanis film tersebut. Terlihat dari Tabel 1 , tambahan NP-ZnO berpengaruh nyata pada ketebalan film yang dihasilkan. Hal ini sesuai dengan pendapat Li et al. (2010) dan Shankar et al. (2015) yang keduanya menyatakan bahwa penambahan nanopartikel $\mathrm{ZnO}$ mampu meningkatkan ketebalan film berbasis polivinil klorida dan gelatin. Pada penelitian $\mathrm{Li}$ et al. (2010), penambahan larutan nanopartikel $\mathrm{ZnO}$ berkonsentrasi $5 \mathrm{~g} / \mathrm{L}$ mampu meningkatkan ketebalan film berbasis PVC sebesar $\pm 2-5 \mu \mathrm{m}$, sedangkan hasil pengamatan Shankar et al. (2015) menunjukkan bahwa penambahan nanopartikel $\mathrm{ZnO}$ pada film berbasis gelatin meningkatkan ketebalan film $\pm 6-11 \mu \mathrm{m}$. Sementara itu, penambahan emulsi lilin lebah secara nyata berpengaruh terhadap ketebalan film berbasis kitosan. Film yang diberi penambahan emulsi lilin lebah menebal hingga lebih dari dua kali lipat karena total padatan dalam larutan film bertambah ketika dilakukan penambahan emulsi lilin lebah. Penambahan lilin lebah pada film berbasis kitosan terbukti mampu meningkatkan ketebalan film hingga 2-8 kali lipat tergantung banyaknya lilin lebah yang ditambahkan. Apabila kandungan lemak atau minyak pada larutan film meningkat, kontak molekul yang lebih besar antara kitosan dan senyawa lemak atau minyak dapat melemahkan gaya agregasi rantai polimer yang menyebabkan matriks lebih terbuka (Velickova et al., 2013; Hromis et al., 2015).

\section{Warna film}

Warna film secara tidak langsung dapat digunakan sebagai tolok ukur warna pelapis. Pada umumnya, nilai $\Delta \mathrm{E}$ film sering digunakan sebagai pertimbangan sebelum tahap aplikasi larutan penyalut ke suatu produk pangan. Hasil pengamatan warna film secara visual tanpa bantuan alat dengan jarak baca normal $(25 \mathrm{~cm})$ menunjukkan bahwa penambahan lilin lebah mengubah penampakan film dari transparan menjadi putih, sedangkan penambahan NP$\mathrm{ZnO}$ tidak mengubah penampakan film. Menurut Marques (2012), perubahan warna pada film dapat diidentifikasi oleh mata manusia apabila nilai $\Delta \mathrm{E}$ film $>3$. Analisis menggunakan instrumen mutlak diperlu- kan untuk membuktikan ada tidaknya perubahan dan perbedaan warna tersebut.

Tabel 1. Ketebalan film

\begin{tabular}{lc}
\hline \multicolumn{1}{c}{ Formula film } & Ketebalan $(\mu \mathrm{m})$ \\
\hline Kitosan & $37,62 \pm 0,82^{\mathrm{Aa}}$ \\
Kitosan+NP-ZnO 1\% & $40,48 \pm 0,82^{\mathrm{Ab}}$ \\
Kitosan+NP-ZnO 2\% & $41,90 \pm 0,82^{\mathrm{Ac}}$ \\
Kitosan+lilin lebah 5\% & $84,76 \pm 1,65^{\mathrm{Ba}}$ \\
Kitosan+lilin lebah 5\%+NP-ZnO 1\% & $86,67 \pm 0,82^{\mathrm{Bb}}$ \\
Kitosan+lilin lebah 5\%+NP-ZnO 2\% & $90,48 \pm 0,82^{\mathrm{Bc}}$ \\
\hline
\end{tabular}

Keterangan: Perbedaan huruf (kapital: konsentrasi lilin lebah yang berbeda, kecil: konsentrasi NP-ZnO yang berbeda) menunjukkan perbedaan nyata $(P<0,05)$

Berdasarkan analisis warna secara kuantitatif yang tersaji di Tabel 2, inkorporasi lilin lebah dan $\mathrm{ZnO}$ berpengaruh nyata terhadap nilai $\Delta \mathrm{E}$. Hal ini sesuai dengan pernyataan Hromis et al. (2015) bahwa penambahan minyak atsiri atau lilin lebah berpengaruh terhadap penampakan film kitosan murni secara visual ketika diamati dengan mata manusia (tanpa bantuan alat). Warna putih terjadi akibat rekristalisasi lilin lebah pada suhu ruang yang menyebabkan penurunan transparansi dari film berbasis kitosan. Hal ini sesuai dengan pernyataan Velickova et al. (2013) bahwa penambahan lilin lebah dalam jumlah yang sedikit yaitu $0,25 \%$ telah mampu meningkatkan kekuningan film berbasis kitosan yang terlihat dari nilai hue. Berdasarkan pengukuran menggunakan colorimeter, semakin tinggi konsentrasi lilin lebah yang ditambahkan maka nilai hue yang dihasilkan akan semakin tinggi pula yaitu mendekati $90^{\circ}$. Kelarutan yang tidak sempurna turut menjadi penyebab heterogenitas warna film karena emulsi lilin lebah merupakan suspensi (Rullier-Birat et al., 2015). Sementara itu, inkorporasi NP-ZnO mampu menurunkan nilai a dan menaikkan nilai $b$ sehingga mempengaruhi nilai $\Delta \mathrm{E}$ secara nyata. Hal ini mengindikasikan bahwa tingkat warna hijau dan kuning film meningkat signifikan seiring dengan penambahan NP-ZnO (Meindrawan et al., 2016). Pada penelitiannya, (Kanmani dan Rhim, 2014) juga menyebutkan bahwa NP-ZnO yang berwarna putih turut berperan dalam menurunkan transparansi film berbasis agar dan CMC.

Tabel 2. Komponen warna ( $L$, a dan $b)$ dan total perbedaan warna $(\Delta E)$ film

\begin{tabular}{lcccc}
\hline \multicolumn{1}{c}{ Formula film } & $\mathrm{L}$ & $\mathrm{a}$ & $\mathrm{b}$ & $\Delta \mathrm{E}$ \\
\hline Kitosan & $99,06 \pm 0,04$ & $-0,61 \pm 0,09$ & $2,02 \pm 0,15$ & $2,30 \pm 0,13^{\mathrm{Aa}}$ \\
Kitosan+NP-ZnO 1\% & $98,87 \pm 0,03$ & $-0,88 \pm 0,08$ & $2,84 \pm 0,16$ & $3,17 \pm 0,15^{\mathrm{Ab}}$ \\
Kitosan+NP-ZnO 2\% & $98,96 \pm 0,01$ & $-0,84 \pm 0,09$ & $2,38 \pm 0,22$ & $2,72 \pm 0,22^{\mathrm{Aa}}$ \\
Kitosan+lilin lebah 5\% & $98,30 \pm 0,13$ & $-1,61 \pm 0,02$ & $5,62 \pm 0,18$ & $6,08 \pm 0,20^{\mathrm{Ba}}$ \\
Kitosan+lilin lebah 5\%+NP-ZnO 1\% & $97,67 \pm 0,31$ & $-1,97 \pm 0,08$ & $7,55 \pm 0,33$ & $8,13 \pm 0,38^{\mathrm{Bb}}$ \\
Kitosan+lilin lebah 5\%+NP-ZnO 2\% & $98,48 \pm 0,13$ & $-1,55 \pm 0,11$ & $5,46 \pm 0,56$ & $5,86 \pm 0,57^{\mathrm{Ba}}$ \\
\hline
\end{tabular}

Keterangan: Perbedaan huruf (kapital: konsentrasi lilin lebah yang berbeda, kecil: konsentrasi NP-ZnO yang berbeda) menunjukkan perbedaan nyata $(P<0,05)$ 


\section{Laju transmisi uap air}

Pada penelitian ini, sesuai Gambar 1, inkorporasi $2 \% \mathrm{NP}-\mathrm{ZnO}$ dengan emulsi lilin lebah (formula B1Z2) menciptakan efek sinergis terbaik dalam menurunkan nilai laju transmisi uap air (water vapor transmission rate/WVTR) film. WVTR sendiri merupakan parameter penting yang menggambarkan permeabilitas uap air suatu film atau pelapis.

Secara teoritis, bahan pangan yang terlapisi film atau larutan penyalut dengan nilai WVTR yang rendah akan menurunkan permeabilitas air bahan pangan tersebut. Ketika permeabilitas uap air menjadi rendah, uap air yang ada di lingkungan akan semakin sulit masuk ke dalam bahan pangan yang telah terlapisi sehingga mampu menghambat kerusakan bahan pangan tersebut. Penambahan lilin lebah pada larutan film berbasis kitosan terbukti mampu menurunkan nilai WVTR film secara signifikan. Bagi film yang berbasis lipid-hidrokoloid, penambahan jumlah lipid (misalnya lilin lebah) akan menurunkan permeabilitas air karena pengaruh densitas atau kerapatan lapisan pelapis (Zhang et al., 2014). Pendapat lain menyatakan bahwa penambahan lilin lebah atau komponen hidrofobik ke film menyebabkan peningkatan sifat hidrofobik matriks dan interaksi lipidpolimer serta berpengaruh terhadap kekuatan ikatan rantai. Tingginya kontak atau interaksi antara kitosan dan komponen hidrofobik melemahkan gaya agregasi rantai polimer sehingga menyebabkan penurunan gaya kohesi polimer dan secara keseluruhan meningkatkan sifat hidrofobik dari matriks film. Hal inilah yang menyebabkan permeabilitas film akan menurun jauh (Hromis et al., 2015).

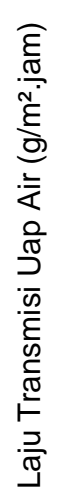

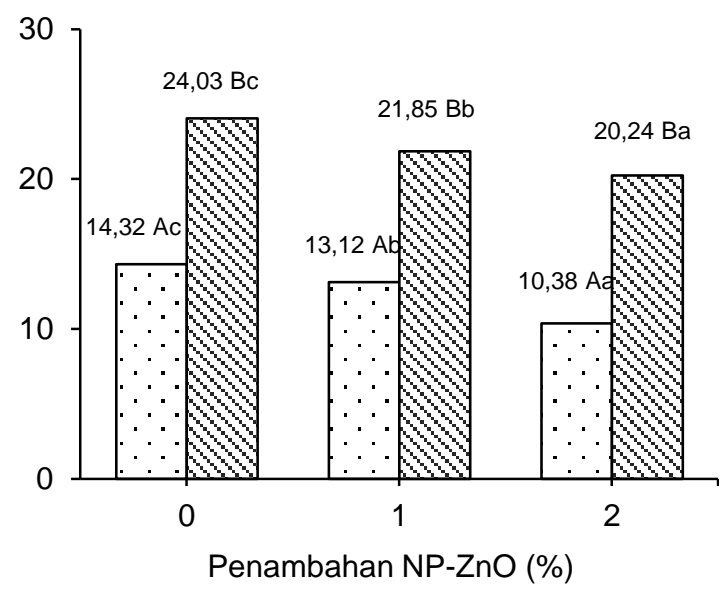

$\square$ Penambahan lilin lebah $\boldsymbol{\Theta}$ Tanpa lilin lebah

Keterangan: Rataan dengan huruf yang berbeda (kapital: konsentrasi lilin lebah, kecil: konsentrasi NP-ZnO) menunjukkan perbedaan nyata $(P<0,05)$

Gambar 1. Laju transmisi uap air film
Selain itu, dari Gambar 1 juga terlihat bahwa penambahan NP-ZnO ikut berpengaruh nyata terhadap penurunan nilai WVTR film. Ketika film kitosanlilin lebah diinkorporasikan dengan NP-ZnO, nilai WVTR yang didapatkan semakin rendah apabila dibandingkan dengan tanpa penambahan NP-ZnO. Semakin tinggi konsentrasi $\mathrm{ZnO}$ yang ditambahkan ke dalam larutan film hidrokoloid, maka nilai WVTR yang didapatkan akan semakin rendah. Hasil ini serupa dengan penelitian Meindrawan et al. (2016) bahwa penambahan $0,5 \% \mathrm{NP}-\mathrm{ZnO}$ pada film berbasis karagenan-lilin lebah mampu menurunkan nilai WVTR dari 37,16 menjadi $33,32 \mathrm{~g} / \mathrm{m}^{2}$ jam. Sementara itu, nilai WVTR film berbasis karagenan-lilin lebah yang diberi penambahan $1 \% \mathrm{NP}-\mathrm{ZnO}$ lebih rendah dibandingkan keduanya yaitu $31,28 \mathrm{~g} / \mathrm{m}^{2} \mathrm{jam}$. Kondisi ini telah dijelaskan Bajpai et al. (2010) dalam penelitiannya bahwa keberadaan nanopartikel $\mathrm{ZnO}$ dalam film berbasis kitosan mampu menurunkan karakteristik hidrofilik film tersebut secara menyeluruh karena berdasarkan pengukuran rasio kontak relatif dan rasio aktivitas, nanopartikel $\mathrm{ZnO}$ menunjukkan sifat hidrofobik yang sangat baik. Pendapat serupa juga dikemukakan Sadeghi dan Shahedi (2016) bahwa seng oksida dalam bentuk nanopartikel mampu terdispersi dalam larutan polimer dan bertindak sebagai pengisi (nano filler) untuk menurunkan permeabilitas uap air film.

\section{Sifat mekanis film}

Parameter yang umum digunakan untuk mencerminkan sifat mekanis suatu film adalah kuat tarik dan elongasi. Berdasarkan hasil penelitian ini, seperti yang terlihat pada Gambar 2, penambahan emulsi lilin lebah dan NP-ZnO memberikan tren nilai kuat tarik film yang cukup jelas. Sementara itu, dari Gambar 3 terlihat bahwa tren nilai persentase elongasi film cenderung acak seiring penambahan emulsi lilin lebah dan NP-ZnO. Hasil ini sedikit berbeda dengan penelitian yang dilakukan oleh EspinoDíaz et al. (2010) serta Rezaei dan Motamedzadegan (2015) yang menyatakan bahwa nilai kuat tarik selalu berbanding terbalik dengan nilai elongasi. Dua penelitian tersebut menyimpulkan bahwa semakin tinggi nilai kuat tarik, maka semakin rendah nilai elongasinya, dan begitu juga sebaliknya. Perbedaan ini diduga kuat akibat tidak meratanya ketebalan suatu film yang digunakan saat analisis kuat tarik dan elongasi. Penggumpalan emulsi lilin lebah di beberapa titik dan tidak meratanya NP-ZnO saat casting film menyebabkan tidak meratanya ketebalan film. Padahal, tebal film berperan penting dalam perhitungan nilai kuat tarik dan elongasi. Hal ini juga diungkapkan oleh Bertuzzi et al. (2012) yang menyatakan bahwa ketebalan film merupakan faktor penting dalam perhitungan nilai kuat tarik dan elongasi. 
Apabila dicermati, Gambar 2 dan Gambar 3 menunjukkan bahwa penambahan emulsi lilin lebah berpengaruh signifikan terhadap penurunan kuat tarik film namun tidak berpengaruh signifikan pada elongasi film. Penambahan senyawa lipid seperti lilin lebah menyebabkan perubahan sifat pada matriks film sehingga lebih lentur. Hal ini sesuai dengan hasil penelitian Velickova et al. (2013) yang menyatakan bahwa inkorporasi lilin lebah pada matriks polimer menyebabkan diskontinuitas pada struktur polimer yang mempengaruhi sifat mekanis film menjadi kurang kaku. Pada penelitian lain, Rullier-Birat et al. (2015) menyatakan bahwa penurunan kuat tarik dan elongasi dapat terjadi akibat heterogenitas struktur pelapis yang memicu melemahnya interaksi intermolekul. Tetesan emulsi lilin lebah mampu menginduksi pelumasan pada kitosan sehingga mampu meningkatkan fleksibilitas film kitosan.

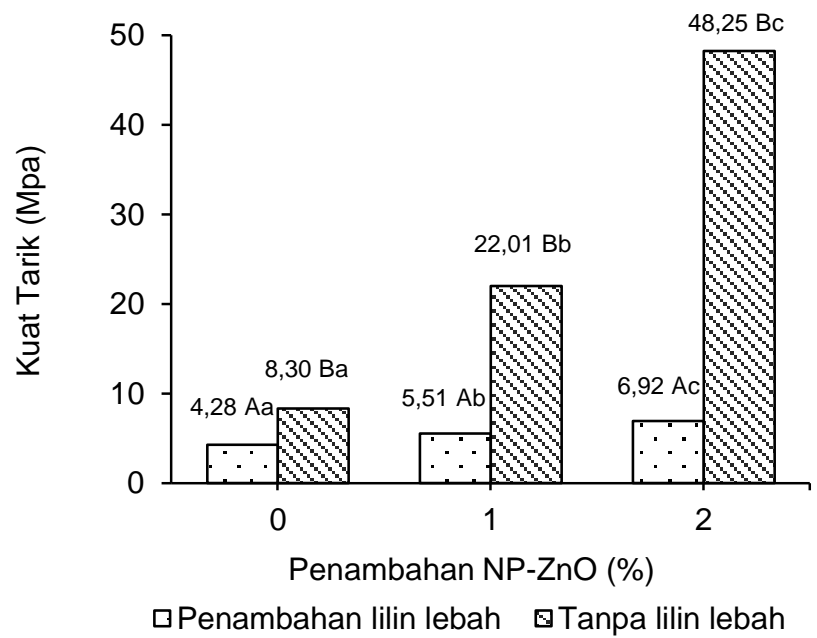

Keterangan: Rataan dengan huruf yang berbeda (kapital: konsentrasi lilin lebah, kecil: konsentrasi NP-ZnO) menunjukkan perbedaan nyata $(P<0,05)$

\section{Gambar 2. Kuat tarik film}

Apabila dilihat dari aspek inkorporasi NP-ZnO ke film, terlihat bahwa peningkatan konsentrasi NP$\mathrm{ZnO}$ cenderung berbanding lurus dengan peningkatan nilai kuat tarik film. Hal ini sesuai dengan penelitian yang dilakukan $\mathrm{Li}$ et al. (2009), bahwa penambahan nanopartikel $\mathrm{ZnO}$ hingga $2 \%$ dari bobot polimer ke film berbasis poliuretan mampu meningkatkan nilai kuat tarik film namun tidak dengan fleksibilitasnya. Berdasarkan hasil analisis dalam penelitian ini, terlihat bahwa lilin lebah dan nanopartikel $\mathrm{ZnO}$ mempunyai efek yang bertolak belakang terhadap nilai kuat tarik dari film. Sementara itu, terlihat juga bahwa penambahan NP-ZnO secara signifikan meningkatkan nilai elongasi film. Hal ini bertentangan dengan penelitian yang dilakukan Espitia et al. (2013) yang mendapatkan hasil bahwa koefisien regresi linear dari NP-ZnO bernilai negatif terhadap elongasi, yang mengindikasikan bahwa semakin rendah konsentrasi NP-ZnO pada film maka nilai elongasinya akan semakin tinggi. Perbedaan ini diduga karena tidak meratanya ketebalan film sehingga permukaan film yang dihasilkan pada penelitian ini cenderung bergelombang dan tidak rata. Hal ini sedikit banyak berpengaruh terhadap hasil pengukuran nilai elongasi. Bagian film yang lebih tipis tentu akan mudah putus, sobek dan kurang elastis dibandingkan bagian film yang lebih tebal.

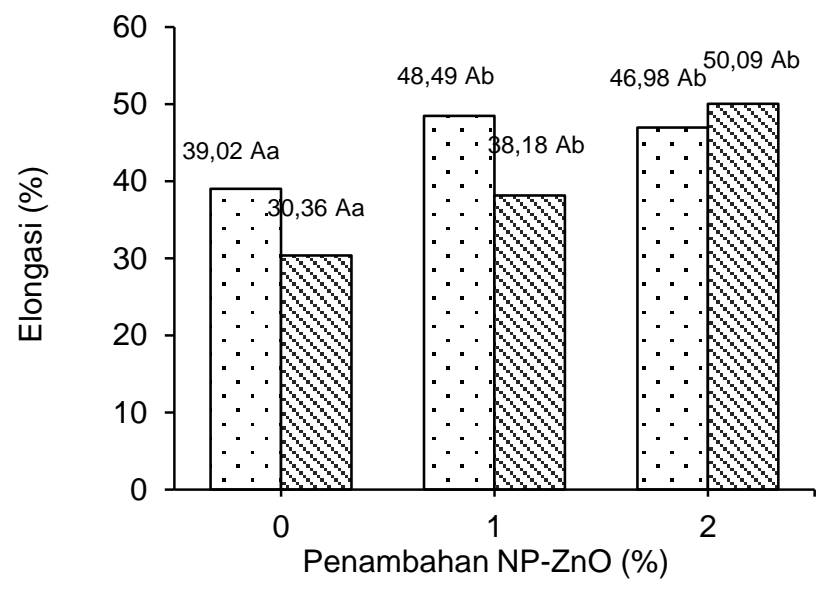

$\square$ Penambahan lilin lebah $₫$ Tanpa lilin lebah

Keterangan: Rataan dengan huruf yang berbeda (kapital: konsentrasi lilin lebah, kecil: konsentrasi NP-ZnO) menunjukkan perbedaan nyata $(P<0,05)$

Gambar 3. Elongasi film

\section{KESIMPULAN}

Tambahan lilin lebah dan NP-ZnO terbukti mampu memengaruhi sifat fisik dan mekanis film berbasis kitosan secara nyata. Dari berbagai formula yang diuji, film berbasis kitosan dengan tambahan $5 \%$ emulsi lilin lebah lilin lebah dan 2\% NP-ZnO menghasilkan perubahan yang paling signifikan terutama aspek permeabilitas uap air dengan nilai WVTR sebesar $10,38 \mathrm{~g} / \mathrm{m}^{2}$ jam. Setelah ditelaah lebih lanjut, peningkatan ketebalan, turunnya nilai WVTR dan nilai kuat tarik serta munculnya nilai elongasi yang cukup stabil (lebih dari $40 \%$ ) yang tidak terikat dengan nilai kuat tarik film menunjukkan bahwa inkorporasi emulsi lilin lebah dan NP-ZnO berjalan dengan baik dengan kitosan. Dapat disimpulkan bahwa film berbasis kitosan dengan tambahan lilin lebah dan NP-ZnO lebih menjanjikan untuk digunakan sebagai pelapis dibandingkan film kitosan tunggal. Meskipun demikian, perlu dilakukan studi lebih lanjut tentang penyalutan secara langsung terhadap produk pangan untuk mengetahui potensinya dalam 
mempertahankan mutu dan umur simpan produk pangan tersebut.

\section{UCAPAN TERIMA KASIH}

Terima kasih kepada Balai Besar Penelitian dan Pengembangan Pascapanen Pertanian atas bantuan pembiayaan dan fasilitas dalam penelitian ini.

\section{DAFTAR PUSTAKA}

[ASTM] American Society for Testing and Materials (US). 1993. Standard test method for water vapor transmission rate through plastic film and sheeting using a modulated infrared sensor. Annual book of American Standard Testing Methods: D1249-90. Philadelphia.

[ASTM] American Society for Testing and Materials (US). 2002. Standard test methods for tensile properties of plastics. Standard Designation: D 882-02. Philadelphia.

Abbasi NA, lqbal Z, Maqbool M, Hafiz IA. 2009. Postharvest quality of mango (Mangifera indica L.) fruit as affected by chitosan coating. Pak J Bot 41: 343-357.

Al-Naamani L, Dobretsov S, Dutta J. 2016. Chitosan-zinc oxide nanoparticle composite coating for active food packaging applications. Innov Food Sci Emerg Technol 38: 231-237. DOI: 10.1016/j.ifset.2016.10.010.

Bajpai SK, Chand N, Chaurasia V. 2010. Investigation of water vapor permeability and antimicrobial property of zinc oxide nanoparticles-loaded chitosan-based edible film. J Appl Polym Sci 115: 674-683. DOI: 10.1002/app.30550.

Bertuzzi MA, Gottifredi JC, Armada M. 2012. Mechanical properties of a high amylose content corn starch based film, gelatinized at low temperature. Braz J Food Technol 15: 219-227. DOI: 10.1590/S1981-67232012005000015.

Elsabee MZ, Abdou ES. 2013. Chitosan based edible films and coatings - a review. Mater Sci Eng C 33: 1819-1841. DOI: 10.1016/j.msec.2013.0 1.010 .

Espino-Díaz M, de Jesús Ornelas-Paz J, MartínezTéllez MA, Santillán C, Barbosa-Cánovas GV, Zamudio-Flores PB, Olivas Gl. 2010. Development and characterization of edible films based on mucilage of Opuntia ficus-indica (L.). J Food Sci 75: 347-352. DOI: 10.1111/j.1750-3841.20 10.01661.x.
Espitia PJP, Soares NFF, Teofilo RF, Coimbra JSR, Vitor DM, Batista RA, Ferreira SO, Andrade NJ, Medeiros EAA. 2013. Physical-mechanical and antimicrobial properties of nanocomposite films with pediocin and $\mathrm{ZnO}$ nanoparticles. Carbohydr Polym 94: 199-208. DOI: 10.1016/j.carb pol.2013.01.003.

Fernandez-Saiz P, Lagaron JM, Ocio MJ. 2009. Optimization of the biocide properties of chitosan for its application in the design of active films of interest in the food area. Food Hydrocolloid 23: 913-921. DOI: 10.1016/j.foodhyd.200 8.06.001.

Fratini F, Cilia G, Turchi B, Felicioli A. 2016. Beeswax: A minireview of its antimicrobial activity and its application in medicine. Asian Pac J Trop Med 9: 839-843. DOI: 10.1016/j.apjtm.20 16.07.003.

Hromis NM, Lazic VL, Markov SL, Vastag ZG, Popovic SZ, Suput DZ, Dzinic NR, Velicanski AS, Popovic LM. 2015. Optimization of chitosan biofilm properties by addition of caraway essential oil and beeswax. J Food Eng 158: 86-93. DOI: 10.1016/j.jfoodeng.2015.01.001.

Kanmani P, Rhim JW. 2014. Properties and characterization of bionanocomposite films prepared with various biopolymers and $\mathrm{ZnO}$ nanoparticles. Carbohydr Polym 106: 190-199. DOI: 10. 1016/j.carbpol.2014.02.007.

Karbowiak T, Debeaufort F, Voilley A. 2007. Influence of thermal process on structure and functional properties of emulsion-based edible films. Food Hydrocolloid 21: 879-888. DOI: 10. 1016/j.foodhyd.2006.07.017.

Li H, Li F, Wang L, Sheng J, Xin Z, Zhao L, Xiao H, Zheng Y, Hu Q. 2009. Effect of nano-packing on preservation quality of Chinese jujube (Ziziphus jujuba Mill. var. Inermis (Bunge) Rehd). Food Chem 114: 547-552. DOI: 10.1016/j.food chem.2008.09.085.

Li XH, Xing YG, Jiang YH, Ding YL. 2010. Antibacterial and physical properties of poly(vinyl chloride)-based film coated with $\mathrm{ZnO}$ nanoparticles. Food Sci Tech Int 16: 225-232. DOI: 10.1177/ 1082013209353986.

Marques SCP. 2012. Edible coatings based on chitosan-beeswax emulsions [Disertasi]. Lisbon: Universidade Nova de Lisboa.

Meindrawan B, Suyatma NE, Muchtadi TR, Iriani ES. 2016. Preparation and characterization of bionanocomposite films made from carrageenan, beeswax and $\mathrm{ZnO}$ nanoparticles. Mater Sci Forum 872: 157-161. DOI: 10.4028/www. scientific.net/MSF.872.157. 
Ramnanan-Singh R. 2012. Formulation and thermophysical analysis of a beeswax microemulsion and the experimental calculation of its heat transfer coefficient [Tesis]. New York: The City University of New York.

Rezaei M, Motamedzadegan A. 2015. The effect of plasticizers on mechanical properties and water vapor permeability of gelatin-based edible films containing clay nanoparticles. World J Nano Sci Eng 5: 178-193. DOI: $10.4236 /$ wjnse.2015.540 19.

Rullier-Birat B, Cazalbou S, Nassar MA, Sandrine C, Tourrette A. 2015. New backing layer for transdermal drug delivery systems: coatings based on fatty acid and beeswax on chitosan films. $J$ Adhes Sci Technol 29: 245-255. DOI: 10.1080/ 01694243.2014 .981982$.

Sadeghi K, Shahedi M. 2016. Effect of zinc oxide nanoparticles on barrier and mechanical properties of $\mathrm{EVOH}$ nanocomposite film incorpora- ting with plasticizer. J Food Nutr Res 4: 709712. DOI: 10.12691/jfnr-4-11-2.

Sekhon BS. 2014. Nanotechnology in agri-food production-an overview. Nanotechnol Sci Appl 7: 31-53. DOI: 10.2147/NSA.S39406.

Shankar S, Teng X, Li G, Rhim JW. 2015. Preparation, characterization, and antimicrobial activity of gelatin/ZnO nanocomposite films. Food Hydrocolloid 45: 264-271. DOI: 10.1016/j.food hyd.2014.12.001.

Velickova E, Winkelhausen E, Kuzmanova S, Moldao-Martins M, Alves VD. 2013. Characterization of multilayered and composite edible films from chitosan and beeswax. Food Sci Technol Int 21: 83-93. DOI: 10.1177/108201321 3511807.

Zhang W, Xiao H, Qian LY. 2014. Enhanced water vapour barrier and grease resistance of paper bilayer-coated with chitosan and beeswax. Carbohydr Polym 101: 401-406. DOI: 10.1016/j. carbpol.2013.09.097. 